\title{
PERSPEKTIF PENEGAKAN HUKUM TERHADAP BARANG-BARANG ILEGAL DI PASAR BEBAS
}

\author{
H. Cecep Wiharma \\ Dosen Fakultas Hukum Universitas Suryakancana dan sebagai Wakil Dekan \\ III Fakultas Hukum Universitas Suryakancana
}

\begin{abstract}
ABSTRAK
Kejahatan tidak akan hilang dengan sendirinya, sebaliknya kasus kejahatan semakin sering terjadi dan yang paling dominan adalah jenis tindak pidana terhadap harta kekayaan, khususnya yang termasuk di dalamnya adalah tindak pidana penadahan. Tindak pidana terhadap harta benda akan tampak meningkat di negara-negara berkembang, kenaikan ini sejalan dengan perkembangan dan pertumbuhan ekonomi, faktor lingkungan dan ekonomi serta tidak sedikit terseretnya anggota masyarakat pada kasus penadahan.
\end{abstract}

Kata Kuci : Tindak Pidana terhadap barang-barang Ilegal.

\begin{abstract}
Evil will not disappear by itself, otherwise crimes are becoming more frequent and the most dominant type of criminal offense against property, particularly those included in it is a criminal offense fencing. Criminal offenses against property will become increasingly prevalent in developing countries, the increase is in line with economic growth and development, environmental and economic factors, and not least the slide members of the public in the case offencing
\end{abstract}

Keywords : Crime against Illegal goods.

\section{PENDAHULUAN.}

Pembangunan di bidang hukum ini bertujuan untuk mewujudkan suatu keadilan yang merata materil dan spiritual berdasarkan Pancasila dan UndangUndang Dasar 1945, dalam wadah Negara Kesatuan Republik Indonesia yang merdeka, berdaulat, bersatu dan berkedaulatan rakyat dalam suasana kehidupan bangsa yang aman, tentram, tertib dan dinamis dalam lingkungan pergaulan dunia yang merdeka, bersahabat, tertib dan damai. ${ }^{1}$

Sebagaimana diketahui keberhasilan pembangunan telah terbukti menimbulkan perubahan-perubahan besar, baik yang bersifat fisik dan kebendaan

Sunryati Hartono, Politik Hukum Menuju Satu Sistem Nasional, Alumni, Bandung, 1991, hlm. 3. 
maupun yang menyangkut tata nilai, perilaku, sikap, kebutuhan masyarakat dan hukum. Salah satu dari perubahan-perubahan besar tersebut adalah perubahan dibidang hukum yang antara lain meliputi isi, bentuk, proses, alat perlengkapan maupun sarana dan prasarana.

Seiring dengan meningkatnya perkembangan kehidupan masyarakat yang begitu cepat sebagai hasil dan proses pelaksanaan perkembangan disegala bidang kehidupan sosial telah membawa pula dampak negatif berupa peningkatan kualitas dan kuantitas berbagai macam kejahatan yang sangat merugikan dan meresahkan masyarakat seperti pencurian, perampokan, penganiayaan, pembunuhan, perkosaan, tawuran remaja atau lebih dikenal dengan "kejahatan jalanan" (street crime) menjadi tantangan bagi proses penegakan hukum. ${ }^{2}$

Kejahatan tidak akan hilang dengan sendirinya, sebaliknya kasus kejahatan semakin sering terjadi dan yang paling dominan adalah jenis kejahatan terhadap harta kekayaan, khususnya yang termasuk di dalamnya adalah tindak pidana penadahan.

Kejahatan dapat diartikan secara kriminologis dan yuridis. Kejahatan dalam arti kriminologis yaitu perbuatan manusia yang menodai norma-norma dasar dari masyarakat. Hal ini dimaksudkan sebagai perbuatan unsur yang menyalahi aturan-aturan yang hidup dan berkembang di masyarakat. Kejahatan secara yuridis yaitu perilaku jahat atau perbuatan jahat dalam arti hukum pidana maksudnya bahwa kejahatan itu dirumuskan di dalam peraturan-peraturan pidana.

Kenyataan menunjukan, bahwa kejahatan terhadap harta benda akan tampak meningkat di negara-negara berkembang, kenaikan ini sejalan dengan perkembangan dan pertumbuhan ekonomi, faktor lingkungan dan ekonomi banyak menentukan terseretnya anggota masyarakat pada kasus penadahan. Beberapa alasan lain yang memudahkan generasi muda terjerumus dalam jaringan tindak pidana penadahan adalah adanya pihak-pihak atau oknum-oknum tertentu sebagai objek pecarian uang.

Tindak pidana penadahan sebagaimana yang di atur dalam pasal $480 \mathrm{Kitab}$ Undang-Undang Hukum Pidana,dimana salah satu unsur penadahan sering

2 Soerjono Soekanto, Kriminologi Suatu Pengantar. Ghalia Indonesia, Jakarta, 1996, hlm. 6. 
dibuktikan oleh Jaksa Penuntut Umum dalam praktik persidangan sehari-hari adalah unsur culpa, yang berati bahwa si pelaku penadahan dapat dianggap patut harus dapat menyangka asalnya barang dari kejahatan dan jarang dapat dibuktikan bahwa si penadah tahu benar hal itu (asal-usul barang).

Mengingat banyaknya kasus tindak pidana penadahan, bukan saja masalah perorangan atau kelompok tertentu, tetapi juga menjadi masalah nasional. Kasus seperti ini akan dapat mengancam stabilitas nasional, melunturkan ketahanan nasional dan yang paling dikhawatirkan adalah mengganggu kelangsungan pembangunan nasional yang sedang digalakan dewasa ini. Oleh karena itu harus segera mendapat perhatian dan penanganan serius secara bersama-sama antara pemerintah dan masyarakat. Permasalahan yang diangkat dalam penulisan ini mengenai, 1) Apa alasan-alasan umum melakukan penadahan?, dan 2) Bagaimakah penerapan hukum pidana terhadap pembeli barang-barang illegal di pasar bebas (penadahan)?.

\section{PEMBAHASAN.}

\section{A. Alasan-alasan Umum Melakukan Penadahan.}

Masalah sebab-sebab kejahatan pada umumnya selalu merupakan permasalahan yang sangat menarik. Berbagai teori yang menyangkut sebab kejahatan telah diajukan oleh para ahli dari berbagai disiplin dan bidang ilmu pengetahuan. Namun, sampai dewasa ini masih belum juga ada satu jawaban penyelesaian yang memuaskan tentang masalah kejahatan ini.

Meneliti suatu kejahatan harus memahami tingkah laku manusia baik dengan pendekatan deskriptif maupun dengan pendekatan kausal, sebenarnya dewasa ini tidak lagi dilakukan penyelidikan sebab musabab kejahatan, karena sampai saat ini belum dapat ditentukan faktor penyebab pembawa risiko yang lebih besar atau lebih kecil dalam menyebabkan masyarakat tertentu melakukan kejahatan, dengan melihat betapa kompleksnya perilaku manusia baik individu maupun secara berkelompok. Soerjono Soekanto mengemukakan, ada dua faktor yang menyebabkan terjadinya kejahatan yaitu : 
1. Faktor personal, termasuk di dalamnya faktor biologis (umur, jenis kelamin, keadaan mental dan lain-lain) dan psikologis (agresivitas, kecerobohan, dan keteransingan).

2. Faktor situasional, seperti situasi konflik, faktor tempat dan waktu. ${ }^{3}$

Hal lain yang dapat diambil dalam tindak pidana penadahan ini pada umumnya disebabkan oleh dua hal, yaitu : pertama, bagi para pencuri menjanjikan keuntungan besar kepada penjual barang-barang ilegal atau benda yang diperoleh dari kejahatan. Kedua karena kebutuhan untuk memenuhi kebutuhan hidup dan bagi pembeli karena harga yang sangat murah sehingga pembeli tergiur akan barang-barang murah tersebut untuk dibeli.

Berkaitan dengan hal tersebut, perlu kiranya penulis mengetengahkan pendapat dari W.F Maramis yang mengemukakan bahwa ada 3 faktor mengapa seseorang melakukan penadahan, yaitu :

1. Faktor Kepribadian; Masyarakat yang mempunyai kepribadian kurang stabil, serta mempunyai sikap mudah tergiur.

2. Faktor Sosio-Budaya; Di Indonesia, rupanya penadah berasal dari keluarga dengan sosio ekonomi yang kurang. Masyarakat umumnya meremehkan segi hukum atau tidak perduli akan adanya hukum.

3. Faktor Fisik dan Kebiasaan; Ada beberapa tersangka yang melakukan penadahan untuk iseng-iseng saja.Bila tersangka sudah terbiasa melakukan penadahan tadi, maka cenderung untuk melakukannya kembali (kecenderungan semacam ini disebut "positif reinforcement").

Berdasarkan faktor-faktor tersebut diatas penulis cenderung untuk mengaitkan sebab-sebab seseorang melakukan tindak pidana penadahan di samping karena untuk mencari keuntungan juga melakukan penadahan disebabkan oleh beberapa faktor, yaitu:

1. Karena menguntungkan, yaitu suatu perbuatan yang dilakukan seseorang karena adanya keuntungan baik besar maupun kecil dalam penjualan maupun pembelian ilegal.

3 Soerjono Soekanto, Kriminologi Suatu Pengantar. Op. Cit. hlm. 12 
2. Karena keinginan, yaitu suatu kemauan yang kuat yang mendorong pelaku untuk melakukan penadahan.

3. Faktor lingkungan, yaitu suatu keadaan yang mendorong untuk melakukan penadahan, terutama dalam pergaulan.

4. Karena kebiasaan, yaitu sesuatu yang sudah menjadi kebiasaan di dalam diri pelaku untuk melakukan penadahan atau penadahan sebagai mata pencaharian si pelaku.

5. Untuk memenuhi Kebutuhan hidup, yaitu jual beli barang-barang ilegal menjadi dilakukan karena desakan untuk memenuhi kebutuhan hidup si pelaku.

6. Kesempatan, yaitu suatu keadaan yang memungkinkan (memberi peluang) atau keadaan yang mendukung untuk terjadinya sebuah penadahan.

Jadi berdasarkan keterangan di atas tersebut, maka penadahan yang dilakukan oleh terpidana disebabkan oleh berbagai faktor, termasuk juga faktorfaktor yang sudah dijelaskan dengan menggunakan beberapa teori faktor tunggal tersebut di atas.

Pada hakekatnya hukum merupakan suatu aturan dan larangan untuk mengatur tingkah laku manusia dan bersifat memaksa. Hukum memaksa dengan berbagai cara, dengan perantaraan paksaan yang langsung dan yang tidak langsung, peraturan hukum bukanlah memperingatkan, menganjurkan atau meyakinkan, tetapi memerintah, memaksa, walaupun tidak berarti senantiasa dapat dipaksakan.

Sebelum mengetengahkan peraturan perundang-undangan yang mengatur tentang kejahatan khususnya hukum positif yang mengatur tentang tindak pidana penadahan, terlebih dahulu akan menjelaskan mengenai definisi hukum positif itu sendiri sebagai suatu awal titik tolak adanya suatu undang-undang yang khusus mengatur mengenai seluk beluk terhadap semua kejahatan penadahan, yang pada saat ini semakin marak terjadi dikalangan masyarakat Indonesia.

Hukum positif (ius Constitutum) menurut atas pembagian hukum dalam macam-macam pembagian hukum termasuk ke dalam pembagian menurut waktu berlakunya. Selain hukum positif terdapat juga Ius Constitutum yaitu hukum yang 
diharapkan berlaku pada waktu yang akan datang dan hukum asasi (hukum alami), yaitu hukum yang berlaku di mana-mana dalam segala waktu dan untuk segala bangsa di dunia. Hukum ini tidak mengenal batas waktu melainkan berlaku untuk selama-lamanya (abadi) terhadap siapapun juga diseluruh tempat.

Hukum positif (ius Constitutum) adalah hukum yang berlaku sekarang bagi suatu masyarakat tertentu dalam suatu daerah tertentu, atau yang hidup disuatu negara dalam waktu dan tempat yang tertentu pula. Singkatnya hukum positif merupakan hukum yang berlaku bagi suatu masyarakat pada suatu waktu dalam suatu tempat tertentu. Ada sarjana yang menamakan hukum positif itu "Tata Hukum". 4

Menurut Soediman Kartohadiprojo, yang dimaksud dengan tata hukum di Indonesia adalah :

"Hukum yang sekarang berlaku di Indonesia; berlaku berarti, yang memberi akibat hukum kepada peristiwa dalam pergaulan hidup; sekarang menunjukan kepada pergaulan hidup yang ada pada saat ini dan tidak pergaulan hidup yang telah terlampau, pula tidak pergaulan pada masa yang kemidian kita cita-citakan kemudian hari; di Indonesia menunjukan kepada pergaulan hidup yang terdapat di Republik Indonesia dan tidak di Negara lain; tidak di Amerika Serikat, tidak di Rusia, tidak di Fhilipina, dan tidak pula di Australia atau india". 5

Perbuatan-perbuatan pidana menurut sistem KUHP dibagi atas kejahatan (Misdrijven) dan pelanggaran (overtredingen). Pembagian dalam dua jenis ini, tidak ditentukan dengan nyata-nyata dalam suatu pasal KUHP tetapi sudah dianggap demikian adanya, dan ternyata antara lain dari Pasal 4, 5, 39, 45 dan 53 buku ke-1. Buku II adalah tentang kejahatan dan buku III tentang pelanggaran.

Menurut M.v.T pembagian atas dua jenis tadi dibedakan atas perbedaan prinsipiil. Dikatakan, bahwa kejahatan adalah "rechtsdeliten", yaitu perbuatanperbuatan yang meskipun tidak ditentukan dalam undang-undang, sebagai perbuatan pidana, telah dirasakan sebagai onrecht, sebagai perbuatan yang bertentangan dengan tata hukum. Pelanggaran sebaliknya adalah "wetsdeliktern",

4 C.S.T. Kansil, Pengantar Ilmu Hukum dan Tata Hukum Indonesia, Balai Pustaka, Jakarta, 1989, hlm. 73.

5 ,Ibid, hlm. 75. 
yaitu perbuatan-perbuatan yang sifat melawan hukumnya baru dapat diketahui setelah ada wet yang menentukan demikian. ${ }^{6}$

Selain dari pada sifat umum bahwa ancaman pidana bagi kejahatan adalah lebih berat daripada pelanggaran, maka dapat dikatakan bahwa :

1. Pidana penjara hanya diancam pada kejahatan saja.

2. Jika menghadapi kejahatan maka bentuk kesalahan (kesengajaan atau kealpaan) yang diperlukan di situ, harus dibuktikan oleh jaksa, sedangkan jika menghadapi pelanggaran hal itu tidak perlu. Berhubungan dengan itu kejahatan dibedakan pula dalam kejahatan yang dolus dan culpa.

3. Percobaan untuk melakukan pelanggaran tidak dapat dipidana (Pasal 54). Juga pembantuan pada pelanggaran tidak dipidana (Pasal 60).

4. Tenggang kedaluwarsa, baik untuk hak menentukan maupun hak perjalanan pidana bagi pelanggaran adalah lebih pendek daripada kejahatan tersebut masing-masing adalah satu tahun dan dua tahun.

5. Dalam hal perbarengan (concursus) para pemidanaan berbeda buat pelanggaran dan kejahatan. Kumulasi pidana yang ringan lebih mudah daripada pidana berat (Pasal 65, 66,-70).

Perbedaan kejahatan dan pelanggaran tidak menjadi ukuran lagi untuk menentukan pengadilan mana yang berkuasa mengadilinya, seperti dahulunya, oleh karena itu semuanya diadili oleh Pengadilan Negeri. ${ }^{7}$

Pembagian hukum juga yang paling penting yaitu pembagian hukum menurut isinya yang meliputi hukum privat (Hukum Sipil) dan hukum publik (Hukum Negara).

1. Hukum Privat (Hukum Sipil), yaitu hukum yang mengatur hubungan antara perseorangan atau mengatur kepentingan perseorangan.

2. Hukum Publik (Hukum Negara), yaitu hukum yang mengatur hubungan antara Negara dan perseorangan (warga Negara) atau mengatur kepentingan umum. ${ }^{8}$

Moeljatno, Azas-azas Hukum Pidana, Rineka Cipta, Jakarta, 2002, hlm. 71.

Ibid, hlm. 73.

C.S.T. Kansil, Op. Cit, hlm. 75. 
Dalam ilmu hukum pidana dikenal juga tiga macam teknik atau cara untuk merumuskan tindak pidana, yaitu :

1. Perumusan yang hanya memberikan kualifikasinya atau nama yuridisnya, tanpa menentukan unsur-unsurnya. Yaitu hanya nama tindak pidana yang disebutkan, sedangkan pengertian dari nama tindak pidana itu diserahkan kepada doktrin atau ilmu hukum pidana dan praktek peradilan.

2. Perumusan yang hanya menentukan unsur-unsurnya tanpa memberikan kualifikasinya atau hanya yuridisnya. Akan tetapa meskipun demikian oleh doktrin diberikan kualifikasinya atas nama yuridisnya.

3. Perumusan yang selain dari pada memberikan nama kualifikasinya atau nama yuridisnya juga menentukan unsur-unsurnya. ${ }^{9}$

Mengenai perumusan sanksi pidana di dalam pemidanaan terdapat beberapa sistem yaitu :

1. Pemidanaan secara tunggal, yaitu dalam perumusan tindak pidana hanya mencantumkan pidana pokok saja.

2. Sistem pemidanaan secara alternatif, yaitu dalam perumusan tindak pidana terdapat dua macam sanksi pidana berupa pidana pokok yang dicantumkan, biasanya hakim boleh memilih satu diantara dua sanksi tersebut. Perumusan biasanya menggunakan "kata atau".

3. Sistem pemidanaan secara kumulatif alternatif, yaitu dalam perumusan ancaman pidana pokok yang dapat dijatuhkan secara bersamaan atau dapat memilih salah satu pidana pokok dari suatu tindak pidana biasanya menggunakan kata "dan/atau". 10

Penjatuhan sanksi pidana yang dilakukan hakim terhadap terdakwa atas tuntutan penuntut umum terhadap Pasal 481 KUHP yaitu penadahan pemberatan adalah tempat karena unsur-unsur yang terdapat dalam ketentuan yuridis mengenai penadahan yang terdapat dalam ketentuan Pasal 480 KUHP sudah terpenuhi, baik objektif maupun subjektifnya.Selain itu ketentuan khusus yang memberatkan dalam hal ini karena pembiasaan. Bentuk pokok pembentukan

9 Sofyan Sastrawidjaya, Hukum Pidana I, Armico, Bandung, 1990, hlm. 21.

Ibid, hlm. 124. 
undang-undang telah mencantumkan unsur kesengajaan atau opzettelijk sebagai salah satu unsur dalam tindak pidana penadahan.Unsur sengaja merupakan satusatunya unsur subjektif didalam tindak pidana penadahan, yakni unsur yang melekat pada subjek tindak pidana ataupun yang melekat pada pribadi pelakunya. Dengan sendirinya unsur opzettelijk harus didakwakan didalam surat dakwaan, dan karena unsur tersebut didakwakan terhadap seorang terdakwa, dengan sendirinya juga harus dibuktikan disidang pengadilan yang memeriksa perkara terdakwa.

\section{B. Penerapan Hukum Pidana Terhadap Pembeli Barang-Barang Illegal Di Pasar Bebas (Penadahan).}

Secara yuridis mengenai penadahan diatur dalam ketentuan Pasal 480 KUHP. Pengertian penadahan itu tidak dirumuskan secara khusus, namun memiliki pengertian yang lebih luas. Tindak pidana penadahan diatur pada BAB XXXI ( Buku II) KUHP, terdiri dari 3 Pasal (480 s/d 482). Salah satu pasal yakni Pasal 480 KUHP, merupakan tindak pidana penadahan dalam bentuk pokok yang rumusannya berbunyi, di hukum dengan pidana penjara paling lama empat tahun atau pidana denda paling banyak sembilan ratus rupiah. Karena melakukan penadahan (heling) barang siapa membeli, menyewa, menukar, menerima gadai, menerima sebagai hadiah, atau karena ingin mendapat keuntungan, menjual, menukarkan, menggadaikan, membawa, menyimpan atau menyembunyikan, menyewakan, suatu benda yang diketahui atau sepatutnya harus diduga bahwa diperoleh dari kejahatan, dan barang siapa menarik keuntungan dari hasil suatu benda, yang diketahuinya atau sepatutnya harus diduganya bahwa diperoleh dari hasil kejahatan.

Jadi yang dinamakan penadahan atau heling yaitu tindak pidana yang terdapat pada Pasal 480 KUHP. Dalam tindak pidana penadahan terdapat dua jenis barang yang diperoleh dengan kejahatan, yaitu :

1. Barang sebagai hasil kejahatan terhadap kekayaan, yaitu pencurian, pemerasan, pengancaman, penggelapan, penipuan, dan penadahan. 
2. Barang sebagai hasil kejahatan pemalsuan seperti uang palsu, cap palsu, atau surat palsu. ${ }^{11}$

Adapun bentuk jenis perbuatan penadah, diantaranya yaitu :

1. Yang bernada menerima dalam tangannya, yaitu membeli, menyewa, menukar, menerima gadai, menerima sebagai hadiah;

2. Yang bernada melepaskan barang dari tangannya, yaitu menjual, menyewakan, menukarkan, menggadaikan, memberikan sebagai hadiah, ditambah dengan mengangkut, menyimpan dan menyembunyikan.

Bagi perbuatan ke-2 ditambah unsur maksud untuk mendapatkan untung (winstbejag). Penambahan ini tidak diadakan pada perbuatan ke-1.Jadi dapat dikatakan bahwa maksud untuk mendapatkan untung merupakan unsur dari semua penadahan. ${ }^{12}$ Bentuk tindak pidana penadahan baik penadahan dalam bentuk pokok yang merupakan ketentuan yuridis dari tindak pidana penadahan itu sendiri, penadahan ringan dan penadahan dalam bentuk pemberatan semua itu diatur dalam Pasal 480-482.

Penadahan ringan atau biasa yang disebut penadahan ringan diatur dalam Pasal 482 dengan diancam hukuman ringan, yaitu maksimum tiga bulan penjara atau denda enam puluh rupiah seseorang yang menadah barang yang diperoleh dengan pencurian ringan dari Pasal 364 atau penggelapan ringan dari Pasal 373, atau penipuan ringan dari Pasal 379. Adapun hal-hal yang memberatkan tersangka penadahan yaitu yang diatur pada Pasal 481 dengan ancaman pidana menjadi tujuh tahun penjara apabila seseorang terbukti membiasakan melakukan tindak pidana penadahan. Pembiasaan ini, kejahatan-kejahatan yang bersangkutan betulbetul dapat dikatakan dipermudah atau ditolong karena para penjahat sebelumnya sudah tahu menyalurkan barang-barang hasil kejahatan secara aman. sudah pantas bahwa tersangka ini dihukum lebih berat daripada orang-orang yang melakukan pencuriannya atau penggelapannya atau penipuan dan sebagainya. Kemudian adapun hukum pidana tambahan yang diatur dalam Pasal 481 ayat 2, yaitu pelaku penadahan dapat dikenakan hukuman tambahan nomor 1 sampai dengan nomor 4

11 Wirjono Prodjodikoro, Tindak-tindak Pidana Tertentu Di Indonesia, PT Refika Aditama, Bandung, 2010, hlm. 60.

12 Wirjono Prodjodikoro, Ibid, hlm. 61. 
dari Pasal 35, dan dapat pula dikenakan pencabutan hak melakukan pekerjaan pencaharian (beroep). ${ }^{13}$

Berikut contoh singkat mengenai tindak pidana penadahan (khususnya bagi pembeli barang-barang ilegal) :

"Seorang A yang meminjam atau menerima sebagai pembayaran utang sejumlah uang dari B yang memperolehnya dengan mencuri, sedangkan A tahu dan pantas harus dapat mengira bahwa uang itu adalah barang curian? Perbuatan si A memang tidak masuk perbuatan-perbuatan tersebut ke-1 dan ke-2 itu, tetapi dapat dipersoalkan, karena si A ini telah membatu melakukan suatu tindak pidana penadahan juga".

Dari rumusan penadahan sebagaimana contoh di atas, jika dirinci terdiri dari unsur-unsur objektif meliputi perbuatan memiliki (zecht toeiggemen), suatu benda (enig goed), yang sebagian atau seluruhnya milik orang lain. Unsur-unsur subjektif meliputi penadahan dengan sengaja (opzettelijk), dan penadahan melawan hukum (wederrechtelijk). ${ }^{14}$

Ketentuan Pasal 480 KUHP diawali dengan kata "barang siapa" yaitu pelaku tindak pidana sebagai subjek hukum, yaitu pendukung hak dan kewajiban dalam bidang hukum. Pelaku tindak pidana diatur dalam Pasal 55 KUHP, yang menentukan :

1. Dipidana sebagai pelaku tindak pidana :

a. Seseorang yang melakukan, yang menyuruh melakukan dan yang turut serta melakukan perbuatan ;

b. Seseorang yang dengan memberikan atau menjanjikan sesuatu dengan menyalahgunakan kekuasaan atas martabat dengan kekerasan, ancaman atau penyesatan, atau memberikan kesempatan, sarana atau keterangan, sengaja menganjurkan orang lain supaya melakukan perbuatan.

2. Terhadap penganjur hanya perbuatan yang sengaja dianjurkan sajalah yang diperhitungkan, beserta akibat-akibatnya. ${ }^{15}$

Wirjono Prodjodikoro, Ibid, hlm. 63.

14 J. Satrio, Hukum Jaminan Hak Kebendaan Fidusia, Citra Aditya Karya, Bandung, 2002, hlm. 84.

15 Solahudin, Kitab Undang-undang Hukum Pidana, Visimedia, Jakarta, 2009, hlm. 21. 
Ketentuan Pasal 55 KUHP di atas berkaitan dengan pelaku tindak pidana baik kejahatan atau pelanggaran, yang berarti tidak membedakan antara pelaku tindak pidana atas dasar kejahatan maupun pelanggaran.

Pelaku tindak pidana menurut Pasal 55 KUHP di atas dibedakan menjadi empat bagian, yaitu :

1. Yang melakukan (pleger);

2. Yang menyuruh melakukan (doen pleger);

3. Yang turut melakukan (mode pleger);

4. Yang dengan pemberian upah (uitlokker). ${ }^{16}$

Turut mengerjakan terjadinya tindak pidana berarti bersama-sama dengan orang lain atau orang-orang lain mewujudkan tindak pidana.

Dalam mewujudkan tindak pidana itu ada 3 kemungkinan, yaitu :

1. Setiap pelaku masing-masing memenuhi semua unsur dalam rumusan delik dan dapat juga disebut melakukan delik.

2. Salah seorang memenuhi rumusan delik/unsur-unsur dan ada orang lain turut serta.

3. Tiadak seorangpun melakukan perbuatan yang memenuhi unsur-unsur delik seluruhnya, tetapi orang yang bersama-sama mewujudkan delik itu.

Penadahan hampir sama dengan penggelapan yaitu suatu barang yang diperoleh dari hasil kejahatan yang dimuat dalam pasal 372, hanya saja pengelapan waktu dimilikinya barang itu sudah ada di tangan pelaku tidak dengan jalan kejatahan sedangkan penadahan yaitu membantu menjual, menerima atau membeli suatu barang dari hasil kejahatan.

Pada buku II mengatur tentang penadahan yang terdiri dari 3 pasal (480482), adapun jenis-jenis tindak pidana penadahan tersebut, adalah sebagai tersebut

1. Penadahan dalam bentuk pokok;

2. Penadahan dalam bentuk yang diperberat;

3. Penadahan ringan.

16 Sugandhi, KUHP dengan Penjelasannya, Usaha Nasional, Surabaya, 1989, hlm. 68-70. 
Adapun yang dimaksud dengan tindak pidana dengan pemberatan adalah seperti :

1. Tersangka yang sengaja membeli, menukar, menerima gadai, menyimpan, atau menyembunyikan barang yang diperoleh dari kejahatan.

2. Karena mendapatkan upah uang, misalnya seseorang yang diperintahkan untuk menjual suatu barang dan orang yang menjualnya itu sudah mengetahui bahwa barang yang dijualnya itu adalah diperoleh dari kejahatan.

Dalam Pasal 481 juga dirumuskan tiga macam hubungan antara pelaku kejahatan dan yang mempercayakan barangnya yaitu :

1. Hubungan berdasarkan pekerjaan seorang pelaku sehari-hari (berope).

2. Hubungan dimana seorang pelaku mendapat upah untuk menjual ataupun menyimpan barang hasil kejahatan, hubungan berdasarkan pertemanan dalam dunia bisnis

\section{PENUTUP.}

Seseorang melakukam tindak pidana penadahan ini pada umumnya disebabkan oleh dua hal, yaitu : pertama, bagi para pencuri menjanjikan keuntungan besar kepada penjual barang-barang ilegal atau benda yang diperoleh dari kejahatan. Kedua karena kebutuhan untuk memenuhi kebutuhan hidup dan bagi pembeli karena harga yang sangat murah sehingga pembeli tergiur akan barang-barang murah tersebut untuk dibeli.

Penanggulangan tindak pidana penadahan yang dilakukan baik bersifat secara preventif (pencegahan) dan penanggulangan yang bersifat represif (penindakan) serta pre-emitip. Adapun kendala yang dihadapi oleh Kepolisian dalam menanggulangi tindak pidana penadahan barang hasil pencurian adalah faktor dari barang bukti itu sendiri yaitu barang yang sudah ditadah tersebut tidak dalam keadaan yang sama seperti pada saat barang tersebut dicuri sehingga menyulitkan Polisi dalam mengusut keberadaan barang bukti tersebut. 


\section{DAFTAR PUSTAKA}

\section{A. Buku.}

Barda Nawawi Arief, Beberapa Aspek Penegakan Hukum dan Pengambangan Hukum Pidana, PT. Citra Aditya Bakti, Bandung, 1998.

C.S.T. Kansil, Pengantar Ilmu Hukum dan Tata Hukum Indonesia, Balai Pustaka, Jakarta, 1989.

J. Satrio, Hukum Jaminan Hak Kebendaan Fidusia, Citra Aditya Karya, Bandung, 2002.

LEMAIRE, Het Recht In Indonesia, PT. Citra Aditya Bakti, Bandung, 1997.

Moeljatno, Azas-azas Hukum Pidana, Rineka Cipta, Jakarta, 2002.

,Asas-Asas Hukum Pidana, Universitas Press, Gajah Mada, Yogyakarta, 1980.

P.A.F. Lamintang, Delik-Delik Khusus Kejahatan Terhadap Harta Kekayaan, Jakarta, Sinar Grafika, 2009.

Romli Atmasasmita, Capita Selekta Kriminologi, Amrico, Bandung, 1983.

Roni Priatna, Fungsionalisasi Hukum Pidana Terhadap Penggelapan Dalam Penjualan Kendaraan, Fakultas Hukum Unsur, Cianjur, 2010.

Ronny Hanitijo Soemitro, Metodologi Penelitian Hukum dan Jurimetri, GHALIA Indonesia, Jakarta, 1988.

Sofyan Sastrawidjaya, Hukum Pidana I, Armico,Bandung, 1990.

Soerjono Soekanto, Sosilogi Hukum, Bina Aksara, Bandung, 1982.

,Kejahatan dan Penegakan Hukum Di Indonesia, Rineka Cipta, 1996. ,Kriminologi Suatu Pengantar. Galia Indonesia, Jakarta,1996.

Solahudin, Kitab Undang-Undang Hukum Pidana, Visimedia, Jakarta, 2009.

Sugandhi, KUHP dengan Penjelasannya, Usaha Nasional, Surabaya, 1989.

Sunaryati Hartono, Politik Hukum Menuju Satu Sistem Nasional, Alumni, Bandung 1991. 
W.A. Bonger, Pengantar Kriminologi, Pembangunan, Jakarta, 1995.

W.F.C. Van, Hend-en Leerboek Van Het Nederlandse Strafrecht I, S. Gouda Quint-D. Brouwer en Zoon, Arnhem, Martinus Nijhoff, Haarlem. 1953.

Wirjono Prodjodikoro, Azas-azas Hukum Pidana di Indonesia.Eresko, Bandung, 1989.

Wirjono Prodjodikoro, Tindak-tindak Pidana Tertentu Di Indonesia, PT Refika Aditama, Bandung, 2010.

\section{B. Peraturan Perundang-undangan.}

Undang-Undang Dasar Negara Republik Indonesia 1945.

Kitab Undang-Undang Hukum Pidana. 